\title{
ADAPTATION OF THE TWEEN 80 ASSAY WITH A RESOLUTION V FRACTIONAL FACTORIAL DESIGN AND ITS APPLICATION TO RANK Ophiostoma fungi WITH WOOD EXTRACTIVE DEGRADING CAPABILITIES
}

\author{
Paula Herrera $^{1}$, José Navarrete ${ }^{2, \wedge}$, Enrique Werner $^{3}$
}

\begin{abstract}
Wood extractives in radiata pine are the source of the observed pitch problems in the pulp and paper industry. Various methodologies have been studied and used to reduce or eliminate their negative effects. A biological treatment with albino fungi of the Ophiostoma genus, fungi that degrade the lipidic components of extractives, has been proposed as a more environmentally friendly alternative for pitch degradation.

The current methods used to search for Ophiostoma albino strains with the highest degradation rates of wood extractives are labor intensive and require a large amount of resources. The Tween $80^{\circledR}$ Opacity test, an assay designed to measure lipolytic enzyme activity in filamentous fungi, was studied to verify the feasibility of its application as a methodology to rank Ophiostoma albino strains with deresination capabilities.

The Tween $80^{\circledR}$ Opacity Test was first characterized by implementing a non-replicated $2^{\mathrm{k}-\mathrm{p}}$ fractional factorial design of resolution $\mathrm{V}$ for a 5 factors with 16 treatments and then to study the effect of the fungus species on the lipolytic enzyme activity; a randomized one factor general factorial design was conducted. The incubation temperature; antibiotics presence; and Tween $80^{\circledR}, \mathrm{CaCl}_{2}$, and peptone concentrations were investigated in the first experiment. The Ophiostoma species effect was studied in the second experiment. In both experiments, the halo area size, which was formed by the fatty acid-calcium complex precipitate, was the response variable.

The results demonstrated the effectiveness of the Tween $80^{\circledR}$ opacity test to measure the lipolytic enzyme activity of Ophiostoma albino strains. Similarly, the incubation temperature and the concentrations of Tween $80^{\circledR}, \mathrm{CaCl}_{2}$, and bacteriological peptone had the highest statistically significant effect on the response variable. In addition, our data demonstrated that the albino strains from the specie $O$. floccosum exhibited the highest rate of lipolytic enzyme production.
\end{abstract}

Keywords: Factorial design, lipase enzyme activity, Ophiostoma floccosum, Ophiostoma piceae, Ophiostoma piliferum, pitch control.

\footnotetext{
${ }^{1}$ Doctorado en Ciencias e Industrias de la Madera, Departamento de Ingeniería en Maderas, Universidad del Bío-Bío. Concepción. Chile.

${ }^{2}$ Departamento de Ingeniería en Maderas, Universidad del Bío Bío. Concepción. Chile.

${ }^{3}$ Departamento de Ciencias Básicas, Universidad del Bío Bío. Chillán. Chile.

^Corresponding author: jnavarre@ubiobio.cl

Received: 29.11.2013 Accepted: 21.03.2014
} 


\section{INTRODUCTION}

Wood extractives, which are composed mainly of triglycerides, fatty acids, and sterols (Fengel and Wegener 1984), induce the formation of pitch deposits during the fabrication of mechanical pulp (Allen 1980, Martínez et al. 2000). Pitch deposition, among other problems, causes the breakage of paper during its manufacturing, the formation of dust during the printing process, and the increment of effluents toxicity (Farrell et al. 1997, Gutiérrez et al. 2009). In other areas of wood processing also increases drying times, promotes brown stain, and prevents the impregnation of wood (Miller et al. 1983, Flynn 1995, Matsumura 2001, Sundqvist 2002, Malkov et al. 2003).

The wood storage time, the use of chemical additives (Allen 1980, Back and Ekman 2000), and more recently, the use of enzymes and microorganisms have been proposed to reduce their effects (Blanchette et al. 1992, Fujita et al. 1992, Farell et al. 1993, Fischer et al. 1994, Gao et al. 1994, Wang et al. 1995, Rocheleau et al. 1998, Chen et al. 2001, Calero-Rueda et al. 2004).

The biological treatment of wood chips with albino strains from the genus Ophiostoma, which are fungi that degrade resin acids and triglycerides (Blanchette et al. 1992, Gao et al. 1994), is a known strategy that is used to reduce and/or eliminate the pitch formation problems during the production of mechanical pulp (Blanchette et al. 1992). Currently, Cartapip 97, which is also known as Sylvanex ${ }^{\mathrm{TM}}$ and is a fungal inoculum of the albino strain from the species Ophiostoma piliferum, is being commercialized to control the pitch problem in the pulp and paper industry (Farrell et al. 1993). Recent studies have suggested the use of Ophiostoma albino fungi, depending on the lumber final destination, as a potential approach to prevent the occurrence of sapstaining fungi in Radiata pine wood (Held et al. 2003, Navarrete and Sánchez 2010, Berrocal et al. 2012)

Each region throughout the world has its own sapstaining fungal diversity (Seifert 1993, Harrington et al. 2001); consequently, a customized regional biological treatment is needed. The search for new albino strains from the species Ophiostoma floccosum include, among other steps, the isolation of individual spores, the verification of its albino nature, the evaluation of their growth rate in solid and liquid media, their aggressiveness in the colonization of substrates, and quantification using solvent extraction of their pitch reducing capabilities (Held et al. 2003, Navarrete et al. 2005). The best albino strain preselection process, which is based on the best rate of mycelia growth on solid media, does not ensure the discovery of the optimal deresination fungus because this process assumes the fungus having a highest growth rate also has the best capabilities of reducing pitch (Navarrete and Sánchez 2005).

It is clear from these facts that a large amount of resources and number of experiments are needed if a statistically significant result is desired. Therefore, the development of an efficient screening and selection methodology to minimize the use of materials and resources would be advantageous for research in this area (Martínez et al. 2000, Martínez-Iñigo et al. 2000, Held et al. 2003)

The Tween $80^{\circledR}$ opacity test has been successfully used in the detection of lipase activity in pathogenic strains of the genus Candida (Slifkin 2000) in autolysates from filamentous fungal cultures of Fusarium sp., Aspergillus sp., Penicillium sp. (García-Lepe et al. 1997), and, more recently, in the selection of fungal species for the consumption of contaminating oils in petroleum spills in aquatic environments (Gopinath et al. 2005).

The triglycerides contained in the Tween $80^{\circledR}$ reagent are hydrolyzed by fungi due to lipase activity, releasing glycerol and fatty acids within the solid media, which contain calcium salts. The chemical reaction between the fatty acid and the calcium salts results in the formation of a white complex precipitate (Sierra 1957).

Because fungi from the Ophiostoma genus also exhibit significant lipase activity (Gao et al. 1994, Tamerler et al. 2001), we hypothesized that the Tween $80^{\circledR}$ opacity test may be used as a screening methodology to rank the Ophiostoma fungi pitch reducing capability. 
Consequently, the objectives of this study were to a) verify the application of the Tween $80^{\circledR}$ opacity test for albino species from the genus Ophiostoma and (b) to adapt its use to study the bioreducing capacity of certain albino species from the genus Ophiostoma.

\section{MATERIALS AND METHODS}

\section{Part I. Validation of the Tween $80^{\circledR}$ Opacity Test}

\section{Albino fungus for the Tween $80^{\circledR}$ validation assay}

The albino strains used in this study were obtained from the Bioprocess and Biotreatment Laboratory Culture collection of the Department of Timber Engineering at the University of Bio-Bio (Table 1): $\mathrm{PCF}_{2} \mathrm{~A} 3$ and $\mathrm{PCF}_{2} \mathrm{~A} 14$ from the species $O$. piceae; $\mathrm{PLF}_{2} \mathrm{D} 8$ and $\mathrm{PLF}_{1} \mathrm{~A} 7$ from the species O. piliferum; and $\mathrm{FLF}_{1} \mathrm{~A} 65$ and $\mathrm{FLF}_{1} \mathrm{~A} 18$ from the species $O$. floccosum. These strains, which were stored at $-84^{\circ} \mathrm{C}$, were transferred to culture plates containing malt extract and agar (MEA 1,5\%(w/v)) and were maintained at $4^{\circ} \mathrm{C}$ until needed. The albino strains were previously obtained according to the methodology described by Held et al. (2003).

\section{Experimental design}

The opacity test characterization in Tween $80^{\circledR}$ media for the Ophiostoma albino strains was performed using a 5 factor, non-replicated, completely randomized resolution V, 25-1 fractional factorial design. A total of 16 treatments were conducted. The factors analyzed and their levels, which were selected from previous studies with Tween $80^{\circledR}$ in other microorganisms (García-Lepe et al. 1997, Slifkin 2000, Gopinath et al. 2005) were A: bacteriological peptone $\left(8\right.$ and $\left.20 \mathrm{gL}^{-1}\right)$, B: Tween $80^{\circledR}\left(4\right.$ and $\left.10 \mathrm{~mL}^{-1}\right), \mathrm{C}$ : calcium chloride $(0,1$ and $\left.1 \mathrm{gL}^{-1}\right)$, D: temperature $\left(18\right.$ and $25^{\circ} \mathrm{C}$ ) and $\mathrm{E}$ : antibiotics (the presence or absence of chloramphenicol and streptomycin sulfate). The response variable for each of the 6 evaluated strains was the area of the halo formed by the calcium salts precipitate in the Tween $80^{\circledR}$ medium measured at 2, 5, and 8 days of growth. The run order of the randomized treatments is shown in table 2 . Three replicates were performed for each treatment.

\section{Statistical Analyses}

An analysis of variance (ANOVA) was performed for each strain (6) and growth period (2, 5, and 8 days), resulting in a total of 18 ANOVAs. The experimental set up, the treatment-randomized run order, ANOVA, and model adequacy verification were conducted using Design Expert 8,0 software (Stat Ease Inc., Minneapolis, USA).

\section{Tween $80^{\circledR}$ media and culture plate inoculation}

The solid medium for each treatment was prepared with bacteriological peptone (Merck), calcium chloride (Sigma-Aldrich), Tween $80^{\circledR}$ (Sigma-Aldrich), and agar (Difco). The concentrations of the solutions, which were adjusted with distilled water according to the individual treatments, were sterilized at $121^{\circ} \mathrm{C}$ for $20 \mathrm{~min}$. The Tween $80^{\circledR}$ was sterilized separately and subsequently added to the media. The $\mathrm{pH}$ was adjusted to 6,0 using a solution of $\mathrm{NaOH}(1 \mathrm{M})$.

Petri dishes for each treatment were inoculated with a 5 -mm diameter plug acquired from the actively growing margins of the tested strain; a total of 48 plates per strain were incubated according to the established conditions for each treatment.

\section{Halo measurements}

Each plate was placed on a polycarbonate sheet graduated in $\mathrm{mm}$ and the halo diameter, produced by the precipitated calcium salts, was measured at 2, 5, and 8 days of growth. A SMZ645 Nikon stereomicroscope set with a cold light source (Nikon Lamp NI-150) and a 20X magnification level was used. The diameter was used to calculate the area of the halo for each incubated fungus. 


\section{Part II. Quantification of lipase activity in solid Tween $80^{\circledR}$ media}

\section{Fungi species}

A total of 30 albino strains, with 10 strains from each species, were studied (Table 1). The Petri dish inoculation and halo measurements of the precipitated calcium salts were performed as indicated in the previous section.

\section{Experimental design}

A single-factor experiment with three levels of the factor and $n=10$ isolates as replicates were performed. The factor studied was the Ophiostoma genus albino species and the O. floccosum, O. piceae and O. piliferum levels. The response was the area of the halo produced by the precipitated calcium salts in the Tween $80^{\circledR}$ media measured at 2 days of growth.

\section{Statistical analyses}

A single-factor ANOVA with a confidence level of $95 \%$ was developed. The treatment averages of the area of the halo of the calcium precipitate for each species were determined, and Fisher's least significant difference (LSD) for pairwise testing of means was conducted. The experimental set up and the statistical analysis were performed using the Design Expert 8,0 software.

\section{Preparation of culture media with Tween $8^{\circledR}$ and incubation conditions}

The culture media composition, which was determined from the validation assays in Part I (Table 4 and Figure 1), were peptone $\left(8 \mathrm{gL}^{-1}\right)$, calcium chloride $\left(1 \mathrm{gL}^{-1}\right)$, agar $\left(15 \mathrm{gL}^{-1}\right)$, and Tween $80^{\circledR}\left(4 \mathrm{ml} / \mathrm{L}^{-1}\right)$. The Tween $80^{\circledR}$ was sterilized at $121^{\circ} \mathrm{C}$ for 20 min separately and subsequently added to the media. The $\mathrm{pH}$ was adjusted to 6,0 with $1 \mathrm{M} \mathrm{NaOH}$. A total of 150 Petri dishes, with 5 dishes per strain, were inoculated with the 30 albino strains (Table 1 ) and incubated at $25^{\circ} \mathrm{C}$ for 2 days.

Table 1. Albino strains from the genus Ophiostoma used in this study. Each strain corresponds to the individual spore isolated from a direct mating.

\begin{tabular}{|c|c|c|c|c|c|c|c|c|}
\hline $\mathrm{N}^{\circ}$ & Specie & STRAIN & $\mathrm{N}^{\mathrm{o}}$ & Specie & STRAIN & $\mathrm{N}^{\circ}$ & Specie & STRAIN \\
\hline 1 & O. piceae & $\begin{array}{c}\text { PC F2 } \\
\text { A3 * }\end{array}$ & 11 & O.piliferum & $\begin{array}{c}\text { PL F2 } \\
\text { B68 }\end{array}$ & 21 & O.floccosum & $\underset{*}{\text { FL F1 A18 }}$ \\
\hline 2 & o. piceae & $\begin{array}{c}\text { PC F2 } \\
\text { A9 } \\
\end{array}$ & 12 & O.piliferum & $\begin{array}{c}\text { PL F2 } \\
\text { B82 }\end{array}$ & 22 & O.floccosum & FL F1 A55 \\
\hline 3 & o. piceae & $\begin{array}{l}\text { PC F2 } \\
\text { A14 * }\end{array}$ & 13 & O.piliferum & $\begin{array}{c}\text { PL F2 } \\
\text { C57 }\end{array}$ & 23 & O.floccosum & $\underset{*}{\text { FL F1 A65 }}$ \\
\hline 4 & O. piceae & $\begin{array}{c}\text { PC F2 } \\
\text { A29 }\end{array}$ & 14 & O.piliferum & PL F2 D6 & 24 & O.floccosum & FL F1 A94 \\
\hline 5 & o. piceae & $\begin{array}{c}\text { PC F2 } \\
\text { A35 }\end{array}$ & 15 & O.piliferum & $\begin{array}{c}\text { PL F2 D8 } \\
* \\
\end{array}$ & 25 & O.floccosum & FL F1 A 2 \\
\hline 6 & O. piceae & $\begin{array}{c}\text { PC F2 } \\
\text { A68 }\end{array}$ & 16 & O.piliferum & $\begin{array}{c}\text { PL F2 } \\
\text { D88 }\end{array}$ & 26 & O.floccosum & FL F1 A 7 \\
\hline 7 & O. piceae & $\begin{array}{c}\text { PC F2 } \\
\text { A70 }\end{array}$ & 17 & O.piliferum & $\begin{array}{c}\text { PL F2 } \\
\text { C60 }\end{array}$ & 27 & O.floccosum & FL F1 A 8 \\
\hline 8 & o. piceae & $\begin{array}{c}\text { PC F1 A } \\
32\end{array}$ & 18 & O.piliferum & $\underset{1}{\text { PL F1 A }}$ & 28 & O.floccosum & FL F1 A 9 \\
\hline 9 & O. piceae & $\begin{array}{c}\text { PC F1 B } \\
39\end{array}$ & 19 & O.piliferum & $\begin{array}{c}\text { PL F1 A } \\
4\end{array}$ & 29 & O.floccosum & $\begin{array}{c}\text { FL F1 A } \\
11\end{array}$ \\
\hline 10 & o. piceae & $\begin{array}{c}\text { PC F1 C } \\
23\end{array}$ & 20 & O.piliferum & $\begin{array}{c}\text { PL F1 A } \\
7 *\end{array}$ & 30 & O.floccosum & FI F1 A 22 \\
\hline
\end{tabular}

(*): Strains selected for the Tween $80^{\circledR}$ opacity test validation study. 


\section{RESULTS AND DISCUSSION}

The quest for new environmentally friendly technologies to minimize the effect of pitch on the production process of mechanical pulp has led to the search for microorganisms with outstanding enzymatic and growth characteristics to improve the efficiency of these economic activities (Behrendt et al. 1995, Behrendt and Blanchette 1997, Held et al. 2003, Calero-Rueda et al. 2004, Farrell et al. 1993, Gao et al. 1994, Rocheleau et al. 1998). Although our group has been successful in finding and developing microorganisms with these capabilities, in particular, albino strains from the genus Ophiostoma, the task has been time consuming and costly (Navarrete and Sánchez 2005, 2010, Navarrete et al. 2008).

The opacity assay, which is also known as the radial diffusion assay for the detection of lipase activity in agar and initially described by Sierra (1957) appears to be a technique that may help to ease this task. This assay measures the ability of certain fungi to produce lipolytic enzymes that liberate fatty acids in a media enriched with an oily compound, which react with calcium ions, producing an insoluble precipitate around the area of inoculation. This methodology has been used for the detection of dermatophyte fungus and yeast species, especially through the presence or absence of a visible halo around the colony (Slifkin 2000). García-Lepe et al. (1997) used the diameter of the halo formed in this specific media to quantify the potential production of lipolytic enzymes from several autolysates of filamentous fungus and observed that Aspergillus nidulans was an important source of lipases. In addition, the size of the halo has previously been used to detect fungal species with remediation potential, e.g., for the filamentous fungi Fusarium sp., Aspergillus spp., Trichoderma viride, Rhizopus stolonifer and Penicillium spp., which were isolated from environments containing an abundant amount of oil wastes (Gopinath et al. 2005). In our study, we observed a correlation between the size of the halo and the lipolytic capacity of the genus Ophiostoma species and trends that may help to find a species and strain with this genus that more effectively prevent blue stain and/or reduce wood extractives.

\section{Validation of the Tween $80^{\circledR}$ Test}

To validate the application of the Tween $80^{\circledR}$ test to study the lipophilic activity of the Ophiostoma genus fungi, we used a factorial design instead of a one-factor-at-a-time experimental design, a frequently used approach to study fungal growth or metabolite production in solid medium. The former approach allowed us to find enough statistical evidence to discern the existence of interactions among variables. Unfortunately, in many studies, this methodology is not used (Czitrom 1999, Montgomery 2005, Berrocal et al. 2012, Wahid and Nadir 2013). Thus, a non-replicated $2^{\mathrm{k}-\mathrm{p}}$ fractional factorial design of resolution $\mathrm{V}$, with 5 factors and 16 treatments was conducted. In table 2, the responses are plotted, which are the areas of the calcium precipitate of the albino strain of the species $O$. floccosum $\mathrm{FLF}_{1} \mathrm{~A} 18$, one of the six studied species, for each of the 16 treatments at 2,5 , and 8 days of growth. 
Table 2. Fractional factorial experimental design matrix with their actual values for the adaption of the Tween $80^{\circledR}$ opacity test to strains of the genus Ophiostoma showing the area size halo response after 2, 5 and 8 days of incubation for the $O$. floccosum strain $\mathrm{FLF}_{1} \mathrm{~A} 18$.

\begin{tabular}{|c|c|c|c|c|c|c|c|c|c|}
\hline \multirow{3}{*}{ Std } & \multirow{3}{*}{ Run } & \multirow{3}{*}{$\begin{array}{c}\text { Factor } 1 \\
\text { A:Temp } \\
\text { C } \\
\end{array}$} & \multirow{3}{*}{$\begin{array}{c}\text { Factor } 2 \\
\text { B:Antibiotic }\end{array}$} & \multirow{3}{*}{$\begin{array}{c}\text { Factor } 3 \\
\text { C:Tween } 80 ® \\
\mathrm{ml} / \mathrm{L} \\
\end{array}$} & \multirow{3}{*}{$\begin{array}{c}\text { Factor } 4 \\
\mathrm{D}: \mathrm{CaCl}_{2} \\
\mathrm{~g} / \mathrm{L} \\
\end{array}$} & \multirow{3}{*}{$\begin{array}{c}\text { Factor } 5 \\
\text { E:Peptone } \\
\mathrm{g} / \mathrm{L} \\
\end{array}$} & \multicolumn{3}{|c|}{ Incubation time } \\
\hline & & & & & & & Day $2(*)$ & Day $5(*)$ & Day $8(*)$ \\
\hline & & & & & & & $\mathrm{mm}^{2}$ & $\mathrm{~mm}^{2}$ & $\mathrm{~mm}^{2}$ \\
\hline 12 & 1 & 25 & yes & 4 & 1 & 8 & 113 & 396 & 735 \\
\hline 9 & 2 & 18 & no & 4 & 1 & 8 & 113 & 327 & 641 \\
\hline 3 & 3 & 18 & yes & 4 & 0,1 & 8 & 75 & 327 & 553 \\
\hline 4 & 4 & 25 & yes & 4 & 0,1 & 20 & 75 & 264 & 471 \\
\hline 5 & 5 & 18 & no & 10 & 0,1 & 8 & 19 & 207 & 396 \\
\hline 6 & 6 & 25 & no & 10 & 0,1 & 20 & 44 & 207 & 327 \\
\hline 1 & 7 & 18 & no & 4 & 0,1 & 20 & 44 & 327 & 553 \\
\hline 13 & 8 & 18 & no & 10 & 1 & 20 & 44 & 264 & 553 \\
\hline 10 & 9 & 25 & no & 4 & 1 & 20 & 113 & 471 & 735 \\
\hline 2 & 10 & 25 & no & 4 & 0,1 & 8 & 113 & 396 & 641 \\
\hline 8 & 11 & 25 & yes & 10 & 0,1 & 8 & 75 & 264 & 327 \\
\hline 16 & 12 & 25 & yes & 10 & 1 & 20 & 113 & 237 & 471 \\
\hline 7 & 13 & 18 & yes & 10 & 0,1 & 20 & 0 & 157 & 396 \\
\hline 11 & 14 & 18 & yes & 4 & 1 & 20 & 75 & 327 & 553 \\
\hline 15 & 15 & 18 & yes & 10 & 1 & 8 & 44 & 264 & 471 \\
\hline 14 & 16 & 25 & no & 10 & 1 & 8 & 113 & 327 & 471 \\
\hline
\end{tabular}

(*) Each data point represents the average of three replicates.

\section{Relative importance of individual factors}

The ANOVA performed during the validation study for the 6 strains considered demonstrated that the total variability observed in the halo area size is explained, mainly in terms of the relative contribution of the factors and their interactions, by the concentration of calcium chloride, the temperature, and the concentration of Tween $80^{\circledR}$ (Montgomery 2005). In addition, the interaction of calcium chloride and peptone originally were statistically significant.

Table 3 demonstrates that the effect relative importance of the concentration of calcium chloride on the formation of the halo gradually decreases from $39,4 \%$ on day 2 to $17 \%$ by day 8 , with an intermediate value of $35 \%$ by day 5 . The initial importance of this factor can be explained, according Hoshino et al. (1991), Tamerler et al. (2001), and Kontkanen et al. (2006), by the inducing effect of the calcium ion $\left(\mathrm{Ca}^{2+}\right)$ on the microbial lipase activity associated with the processes of excretion of extracellular lipolytic enzymes. According to Hoshino et al. (1991), the metabolic pathway of secretion of these enzymes is controlled by the intracellular concentration of $\mathrm{Ca}^{2+}$ ions using the cellular signal transduction pathways for the activation of repressed lipase production pathways. 


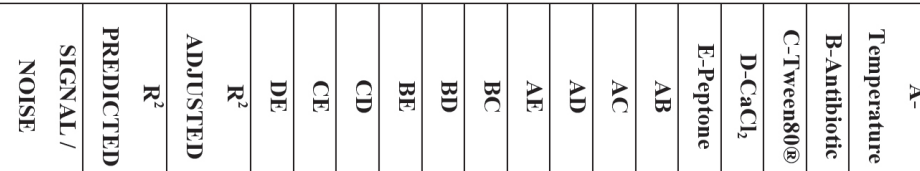

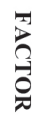

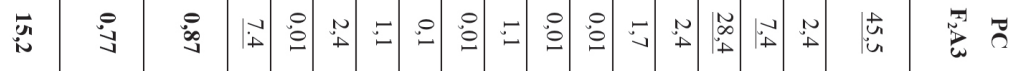

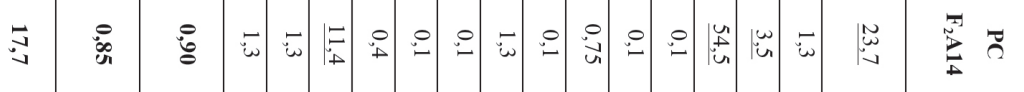

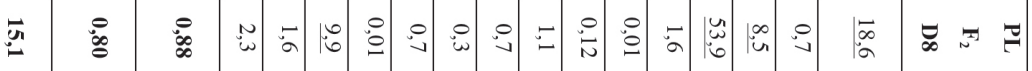

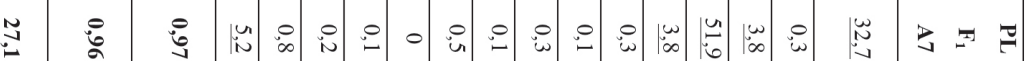

†

吾

党.

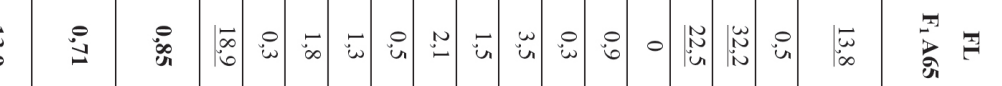

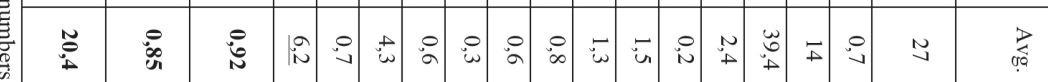

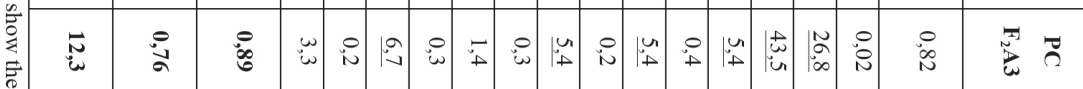

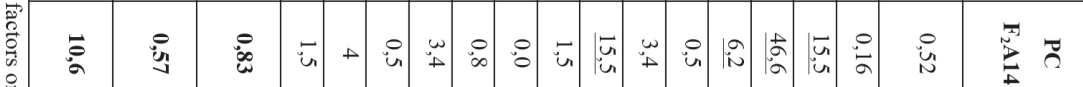

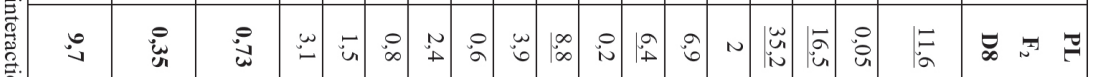

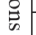

马

1

:

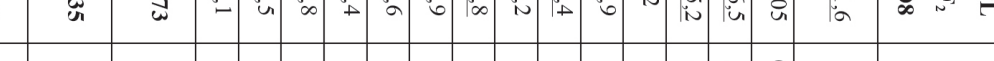

㟀

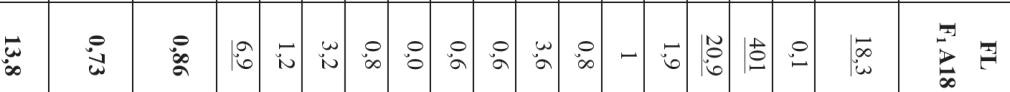

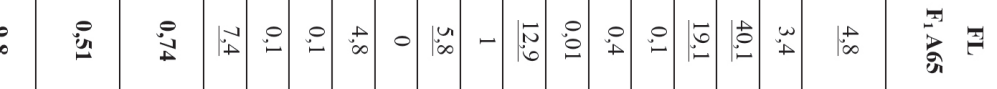

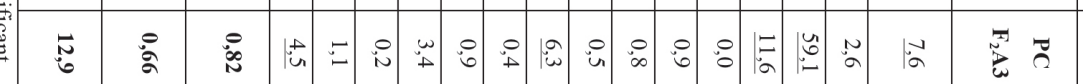

\begin{tabular}{|c|c|c|c|c|c|c|c|c|c|c|c|c|c|c|c|c|}
\hline 6 & in & $\stackrel{5}{i}$ & $|q|$ & $4:$ & & $i$ & 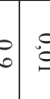 & $\infty$ & $\omega$ & & & $|\%|$ & if & & $\sum_{+2 \pi}^{\pi}$ & \\
\hline $\bar{\omega}$ & 8 & 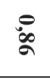 & $|\infty| \infty \mid$ & $\stackrel{8}{\varrho}$ & & $\checkmark$ & : & & & & $\begin{array}{l}0.0 \\
0\end{array}$ & | & $\infty$ & $\vec{b}$ & $\vec{\infty} \approx \square$ & \\
\hline$\infty$ & $\underset{\omega}{D}$ & N & : & 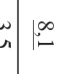 & & is & $i$ & & & $\because 1$ & & $|\stackrel{n}{\infty}|$ & $\dot{\omega}$ & $E$ & $z=\vec{y}$ & \\
\hline 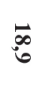 & $\stackrel{\infty}{\infty}$ & 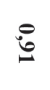 & $\sim$ & $\infty=$ & : & $\stackrel{0}{9}$ & is & $\left.\right|_{\infty} ^{\infty}$ & 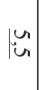 & & & $\left|\begin{array}{l}\infty \\
\infty \\
\infty \\
+\end{array}\right|$ & 管 & E & $\vec{D}_{\infty}^{2}$ & \\
\hline$\ddot{:}$ & $\dot{b}$ & ज्ञ & $|\mp|$ & ${ }_{\infty}$ & & $\infty$ & $\begin{array}{l}0 \\
+\end{array}$ & & lin & & & | & $\overline{\mathrm{N}}$ & 6 & 芴 & \\
\hline & $:$ & $\infty_{\infty}$ & $\sigma$ & $\omega$ & & & & & & & & w & & $\vec{\omega}$ & 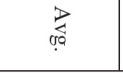 & \\
\hline
\end{tabular}


Table 3 also demonstrates that the relative importance of the effect of temperature decreases between day 2 and 8 , from $27 \%$ to $13 \%$, with an intermediate value of $6 \%$ for day 5 . This decrease in the effect of temperature on the formation of the halo can be explained by its initial effect on the synthesis processes and the secretion of lipases, which once activated do not depend significantly on its effect. In a study with Candida species in a temperature range between $30-35^{\circ} \mathrm{C}$ after 24 hours of incubation, Slifkin (2000) did not observe a significant difference in the occurrence and intensity of the halos at these temperatures.

In contrast to the factors mentioned, the effect of the relative importance of Tween $80^{\circledR}$ increases for the study period from $14 \%$ to $36 \%$, with an intermediate value for day 5 of $25,8 \%$. The increase of the effect on the time of this carbon source is explained by its oily nature, which induces the production and excretion of lipases. Studying the growth of the filamentous fungus Rhizopus oryzae, Shukla and Gupta (2007) observed that the secretion of these enzymes was dependent on the nature of the oily carbon source used. Moreover, the effect of the carbon source on the size of the halo in the species O. floccosum has a more relevant effect on the entire evaluation period, with respect to the strains of the species $O$. piceae and $O$. piliferum, exhibiting a notable difference at 48 hours of growth with respect to these same strains (Table 3).

The relative importance of peptone (the source of nitrogen) on the size of the halo, although significant in the ANOVA of the strains analyzed, is the least relevant factor and only explains approximately $2,8 \%$ of the total variability observed for the days of growth analyzed. The values suggest that this factor is the least important, in general and in the study period, for the species $O$. floccosum. Nevertheless, Gao and Breuil (1995), Elibol and Ozer (2001) and Sharma et al. (2001) suggest that the nitrogen source has a significant effect on the production of microbial lipases. In particular, for a strain of the species $O$. piceae grown in liquid culture medium, these researchers observed that the addition of peptone as well as ammonium sulfate induced lipase production (Gao and Breuil 1995).

The effect of the presence of antibiotics used to prevent the growth of unwanted microorganisms had no statistically significant effect on the development of the halo for any species.

\section{Relative importance of the interactions between variables}

In this study, it was observed that only some of the second-order interactions were significant, of which the $\mathrm{AC}$ interactions (temperature/Tween 80 ), $\mathrm{AD}$ (temperature/calcium chloride), and $\mathrm{DE}$ (calcium chloride/ peptone) were notable for their percentage contribution in the explanation of the total observed variability. The effect on the response variable of the $\mathrm{AC}$ and $\mathrm{DE}$ interactions was maintained during the study period, reaching values as high as $6,2 \%$ (Table 3 ). Nevertheless, for the $\mathrm{AD}$ interaction, the value increased from 1,3 to $7,5 \%$. The effect of the $\mathrm{AC}$ and $\mathrm{AD}$ interactions is explained by the effect that the temperature, which is involved in both interactions, has on the enzymatic hydrolysis reaction of Tween $80^{\circledR}$ as on the calcium ion, which simultaneously acts as an inducer of enzymatic activity and as a precipitating agent of the free acids produced by the reaction (Hoshino et al. 1991). The effect of the DE interaction, however, can also be explained by the induction effect that calcium has on the synthesis of lipases (Hoshino et al. 1991), while peptone is the source of amino acids for the synthesis of these enzymes (Gao and Breuil 1995).

Moreover, the second-order interactions, $\mathrm{AB}, \mathrm{AE}, \mathrm{BC}, \mathrm{BE}, \mathrm{CD}$, and $\mathrm{CE}$, do not obey the pattern observed in the $\mathrm{AC}, \mathrm{AD}$, and $\mathrm{DE}$ interactions. In the first case, these interactions only contribute significantly to the explanation of the total variability observed in at most one biotreatment period. However, for the second set of interactions, their effect is observed in at least two periods of biotreatment, for the $\mathrm{AB}$ and $\mathrm{BE}$ interactions and for the growth period of 5 days, with percentages of 3 and $2 \%$, respectively. Similarly, the same finding occurs for the $\mathrm{CE}$ interaction, which only contributes 3,1\% for the period of 8 days of growth. An explanation for the diverse contributions of these interactions to the explanation of the total variability observed is found in the inherent variability of each strain and species studied. The interactions of the third and fourth order, which are not presented in Table 3, were not statistically significant. 


\section{Correlation coefficients, signal/noise ratio and cube diagrams}

The average adjusted and predicted correlation coefficients and those from the signal/noise ratio indicate that, from the incubation periods studied, the shorter incubation period, with a predicted correlation coefficient of $85 \%$, is the most appropriate for rating the precipitant area (Table 3). The average predicted correlation coefficients for periods of 5 and 8 days, of $61 \%$ and $60 \%$, demonstrate that the mathematical models associated with these ANOVAs explain the lower percentage of the variability observed. Moreover, the greatest value of the signal/noise ratio of approximately 20 for 2 days of incubation, compared with the value of 12 for at 5 and 8 days, demonstrates that in this period, there is a higher probability of detecting statistically significant differences (Table 3).

Figure 1 displays the combined effect of the significant factors, temperature, Tween 80, and calcium chloride, for 2 days of incubation, on the halo area size. The cube plots also show, for both, low and high level of peptone, the predicted responses at each point of the design and the conditions that favor the formation of a halo of maximum area. From their analysis it is concluded that the solid growth medium of the Tween 80 assay, to maximize the halo area, must be prepared without antibiotics, with peptone $(8 \mathrm{~g} / \mathrm{L})$ ) Tween 80 (4 $\mathrm{g} / \mathrm{L}), \mathrm{CaCl}_{2}(1 \mathrm{~g} / \mathrm{L})$, and the test must be performed at a temperature of $25^{\circ} \mathrm{C}$.

\section{DAY 2}
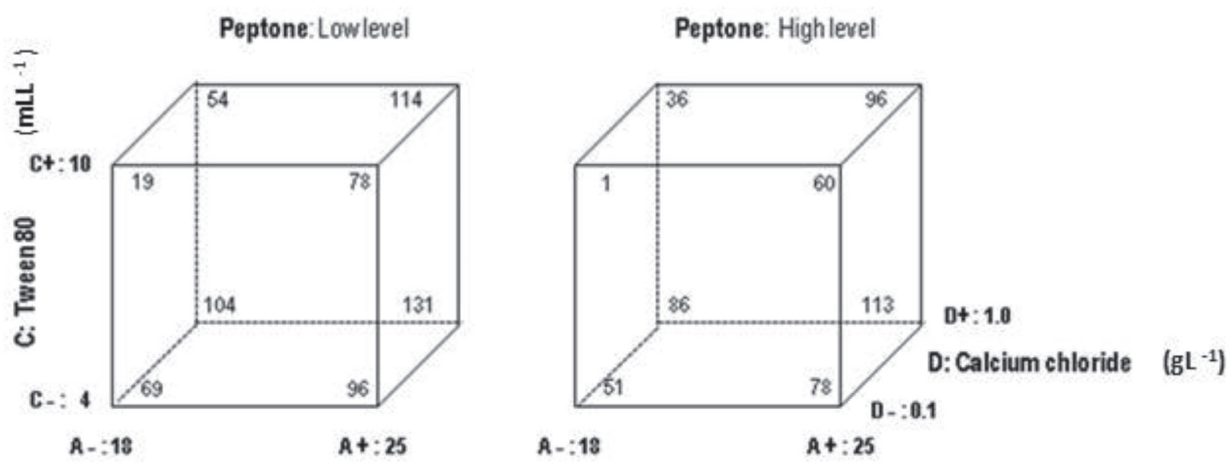

\section{A:Temperature $\left({ }^{\circ} \mathrm{C}\right)$}

Figure 1. Cube diagram of predicted response halo area size by the model derived from the analysis of variance for the strain $O$. floccosum $\mathrm{FLF}_{1} \mathrm{~A} 18$ measured at day 2 as a function of temperature, calcium chloride and Tween 80 , at the lowest $(8 \mathrm{~g} / \mathrm{L})$ and highest level $(20 \mathrm{~g} / \mathrm{L})$ of Peptone.

These results indicate that the Tween $80 \AA$ test is a suitable methodology for identifying albino strains of the species $O$. piceae, $O$. piliferum and $O$. floccosum with better lipase activity and that the optimum levels of the variables for its application are concentrations of $1 \mathrm{~g} / \mathrm{L}$ of $\mathrm{CaCl}_{2}, 4 \mathrm{~g} / \mathrm{L}$ of Tween $80^{\circledR}$, and $8 \mathrm{~g} / \mathrm{L}$ of peptone, with an incubation time of 2 days at $25^{\circ} \mathrm{C}$. 


\section{Evaluation of the effect of the albino fungus species on lipase activity}

The extracellular lipolytic activity of 30 fungi of the $O$. floccosum, O. piceae and $O$. piliferum species, 10 from each species, was evaluated using the Tween $80^{\circledR}$ test adapted to this genre. All of the strains of the species under study, unlike other species of fungi and yeasts, exhibited statistically significant lipolytic activity (Slifkin 2000). For the studied strains, it was observed that the species factor significantly affected the time of formation and the visibility of the halo of the calcium precipitant. The albino strains of $O$. floccosum were the first to form a visible halo at 12 hours of growth, while the strains of $O$. piceae formed a halo at 48 hours (Figure 2). Halo growth for albino strains of $O$. piliferum was observed after approximately 24 hours.

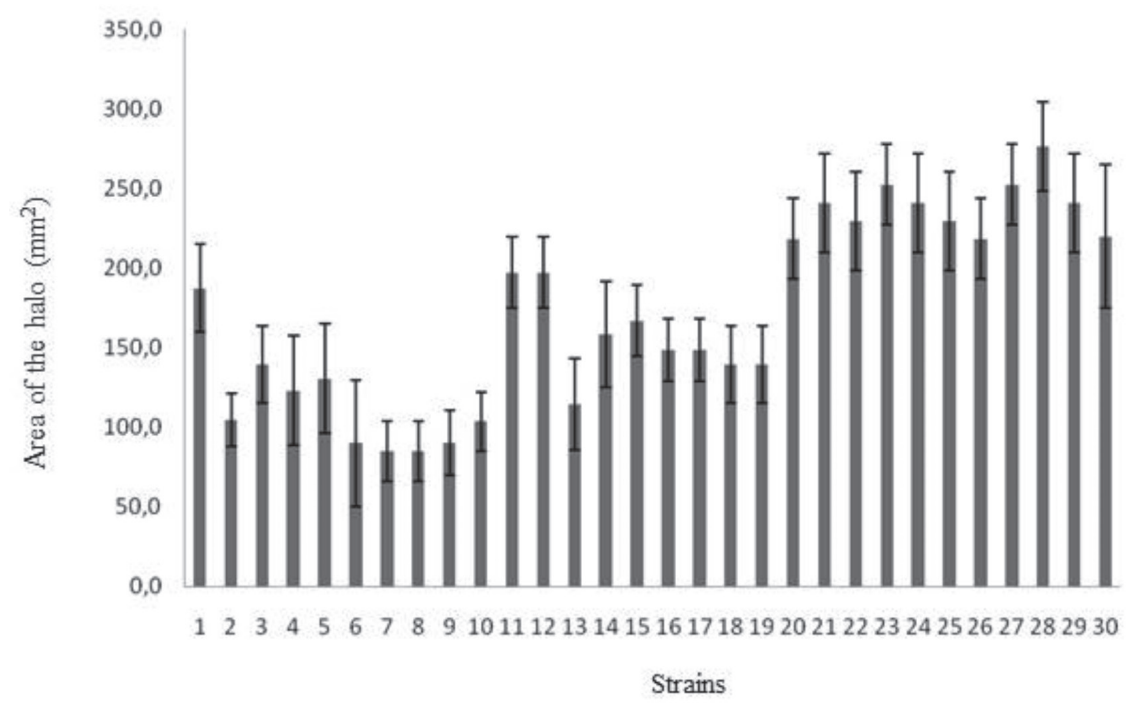

Figure 2. Ophiostoma albino strains halos's area in Tween $80^{\circledR}$ media amended with calcium chloride after $48 \mathrm{~h}$ of incubation at $25^{\circ} \mathrm{C}$.

Note: The numbers in the $\mathrm{x}$-axis correspond to the identification of the strains informed in Table 1

The ANOVA of the factorial design for studying the effect of the species on the halo size demonstrated that the effect of this factor on the size of the halo of the precipitated calcium salts was statistically significant with a $p$ value of less than $0,0001\left(\mathrm{~F}_{0}=51\right)$. Likewise, the values of the predicted and adjusted coefficients of correlation, 0,741 and 0,775 , respectively, indicate that the model explains nearly $75 \%$ of the observed variability. The appropriate statistical prediction indicates that the signal/noise ratio was 14,2, a large enough value to ensure an adequate prediction for the model. The results of the test method for the least significant difference of Fisher's LSD demonstrated that all the possible comparisons of the means were significant (Figure 3). 


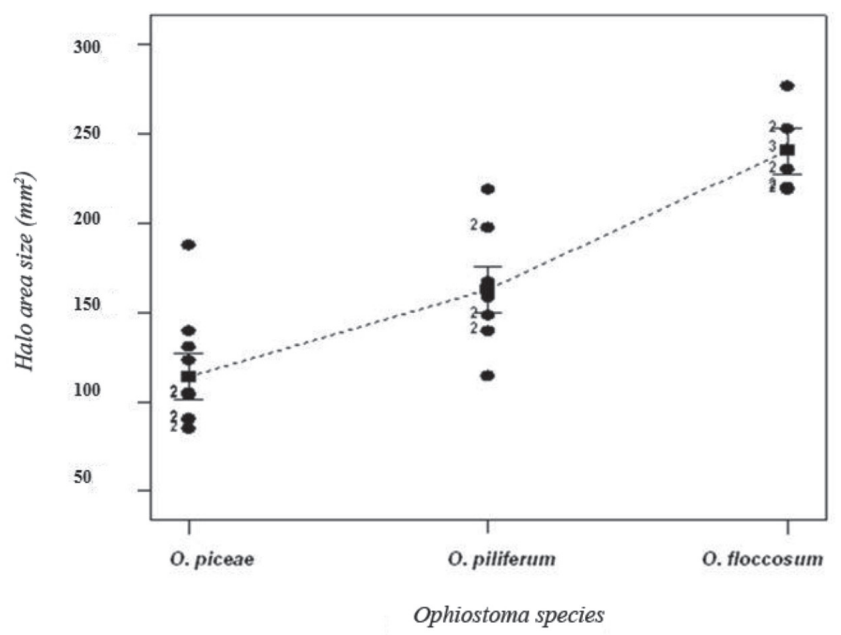

Figure 3. Scatter diagram of halo area size versus Ophiostoma species. Note: Numbers in the figure represent the overlap of data with the same value.

Figure 2 demonstrates that the species $O$. floccosum provides the highest levels of precipitation of the calcium salts of the fatty acids, evaluated at $25^{\circ} \mathrm{C}$ after 48 hours of incubation, which is an indirect measure of the enzymatic activity of this species. This figure also reveals that the evaluated strains of each species have different levels of lipolytic activity. The areas of the halos of the species $O$. piceae, O. piliferum and $O$. floccosum ranged from $84,4-187,4 ; 114,3-218,5$ and $176,4-218,5 \mathrm{~mm}^{2}$, respectively. The major differences between the minimum and maximum values of the halo areas of each population of individuals were observed in the O. piceae and O. piliferum species (Figure 2).

Other authors have corroborated the variability of the enzymatic activity in strains of the same species and in different species. Cihangir and Sarikaya (2004) isolated fungi samples of the genera Aspergillus, Penicillium, Neurospora and Cladosporium, among others, from soil and observed that of the strains analyzed, a strain of the species Aspergillus exhibited the greatest lipase activity. In another study, Colen et al. (2006), also working with soil samples, discovered a strain of the species Colletotrichum gloeosporioides with high lipolytic activity among 59 isolated strains.

No reports have considered the search for or the development of strains with high lipolytic capacity as objectives in the study of albino fungi of the genus Ophiostoma. The screening studies in this area have intended to discover, through stress tests, fungi with a permanent albino character for use as biological control agents. Held et al. (2003) reported obtaining thousands of spores and subsequently evaluating their albino character. The authors selected a large number of albino strains that maintained their albino character and were tested as potential agents for the biological control of blue stain exhibited by fungi such as Leptographium procerum, O. piliferum and Sphaeropsis sapinea. Meanwhile Gao et al. (1994) and Gao and Breuil (1995) directed their work to the characterization of lipases from a strain of the staining species $O$. piceae for its possible application as a reducing agent of lodgepole pine wood extractives. In another study, Martínez et al. (2000) reported the characterization of the lipolytic activity of 90 strains of Basidiomycetes and Ascomycetes fungi that were collected in plantations of Eucalyptus globulus by inoculating sterile splinters from that wood. In addition, Calero-Rueda et al. (2004) conducted a search for fungi capable of degrading extractives from Eucalyptus wood and discovered a strain of the species $O$. piceae that exhibited a great production capacity for lipases and esterases. 
This study, in the context of the search for microorganisms with lipolytic enzymes with exceptional features, provides a simple and robust methodology that minimizes the use of resources while simultaneously reducing the time required to obtain results. The Tween $80^{\circledR}$ assay will be especially useful in the development of microorganisms with this potential, particularly when an early classification of this ability among hundreds of potential microorganisms is desired, as for studies performed with fungi of the genus Ophiostoma.

\section{CONCLUSIONS}

The results of this study demonstrate that the Tween $80^{\circledR}$ test is a suitable methodology for identifying albino strains of the species $O$. piceae, $O$. piliferum and $O$. floccosum with better lipase activity and that the optimum levels of the variables for its application are $1 \mathrm{~g} / \mathrm{L} \mathrm{of} \mathrm{CaCl}_{2}, 4 \mathrm{~g} / \mathrm{L}$ of Tween $80^{\circledR}$, and $8 \mathrm{~g} / \mathrm{L}$ of peptone, with an incubation time of 2 days at $25^{\circ} \mathrm{C}$.

In addition, by applying this methodology, it was possible to determine that the species $O$. floccosum has greater lipase activity compared with the species $O$. piliferum and $O$. piceae and that the species $O$. piliferum has greater lipolytic capacity compared with the species $O$. piceae.

Future studies will aim to relate the genetic variability of the genus Ophiostoma, its enzymatic activity, and the reduction of pitch in extractives of Pinus radiata wood.

\section{ACKNOWLEDGMENTS}

The authors would like to acknowledge the funding provided by the Doctorate in Science and Wood Industries (DOCIM) from Wood Engineering Department at the Bío-Bío University, the Fondef D10i1240 project from FONDEF of Conicyt-Chile, and the Bioprocess and Biotreatment Laboratory of the Wood Engineering Department at the Bío-Bío University

We also acknowledge the support of Dr. Colette Breuil for providing laboratory space for the research work of the DOCIM student Paula Herrera.

\section{REFERENCES}

Allen, L.H. 1980. Mechanism and control of pitch deposition in newsprint mill. Tappi Journal 63 (2): 81-87.

Back, E.L.; Ekman, R. 2000. Definitions of wood resin and its components. Pitch Control, Wood Resin and Deresination. E.L. Back and L.H. Allen (eds.) TAPPI Press. Atlanta. U.S.A. 392p.

Behrendt, C.J. Blanchette, R.A. 1997. Biological Processing of Pine for Pulp and Paper Production with Phlebiopsis gigantea. Appl Environ Microbiology 63 (5) : 1995-2000.

Behrendt, C.J.; Blanchette, R.A.; Farrell, R. 1995. Biological control of blue stain fungi in wood. Phytopathology 85:92-97.

Berrocal, A.; Navarrete, J.; Oviedo, C. 2012. Efecto de diferentes condiciones de crecimiento en el dimorfismo levadura micelio de la cepa albina PCF2A29 de la especie Ophiostoma piceae. Maderas.Ciencia y tecnología 14(1):91-102.

Blanchette, R.; Farrell, R.; Burnes, T.; Wendler, P.; Zimmerman, W.; Brush, T.; Snyder, R. 1992. Biological control of pitch in pulp and paper production by Ophiostoma piliferum. Tappi Journal 75:102-106.

Calero-Rueda, O.; Gutiérrez, A.; Del Río, J.C.; Prieto, A.O.; Plou, F.; Ballesteros, A.; Martínez, A.; Martínez, M.J. 2004. Hydrolysis of sterol esters by an esterase from Ophiostoma piceae: application to pitch control in pulping of Eucalyptus globulus wood. Int J Biotechnology 6 (4): 367-375. 
Chen, S.; Lin, Y.; Zhang, Y.; Wang, X.H.; Yang, J.L. 2001. Enzymatic pitch control at Nanping paper mill. Tappi Journal 84: 44-47.

Cihangir, N.; Sarikaya, E. 2004. Investigation of lipase production by a new isolate of Aspergillus sp. World J Microbial Biotechnol 20: 193-197.

Colen, G.; Gonçalves Junqueira, R.; Moraes-Santos, T. 2006. Isolation and screening of alkaline lipaseproducing fungi from Brazilian savanna soil. World J Microbial Biotechnol 22: 881-885.

Czitrom, V. 1999. One-factor-at a- time versus designed experiments. The American Statistician 53 (2): 126-131.

Elibol, M.; Ozer, D. 2001. Influence of oxygen transfer on lipase production by Rhizopus arrhizus. Process Biochem 36: 325-329.

Farrell, R.; Blanchette, R.A.; Brush, T.; Hadar, Y.; Iverson, S.; Krisa, K.; Wendler, P.; Zimmerman, W. 1993. Cartapip a biopulping product for control of pitch and resin acid problems in pulp mills. J Biotechnol 30:115-122.

Farrell, R.; Duncan, S.; Ram, A.; Kay, S.; Hadar, E.; Hadar, Y.; Blanchette, R.; Harrington, T.; McNew, D. 1997. Causes of sapatain in New Zealand. In Proceedings of a Symposium at the Forest Reasearch Institute, Rotorua, New Zealand. pp. 27-29.

Fengel, D.; Wegener, G. 1984. Extractives. In: Wood chemistry, ultrastructure, reactions. Walter de Gruyter, Berlin. pp. 182-226.

Fischer, K.; Akhtar, M.; Blanchette, R.; Burnes, T.A.; Messner, K.; Kirk, T.K. 1994. Reduction of resin content in wood chips during experimental biological pulping processes. Holzforschung 48: 285-290.

Flynn, K. 1995. A review of permeability, fluid flow and anatomy of spruce (Picea spp.) Wood Fiber Sci 27(3):105-118

Fujita, Y.; Awaji, H.; Taneda, H.; Matsukura, M.; Hata, K.; Shimoto, H.; Sharyo, M.; Sakaguchi, H.; Gibson, K. 1992. Recent advances in enzymatic pitch control. Tappi Journal 75(4): 117-122.

Gao Y.; Breuil, C.; Chen, T. 1994. Utilization of triglycerides, fatty acids and resin acids in lodgepole pine wood by a sapstaining fungus Ophiostoma piceae. Materials and Organisms 28:105-118.

Gao Y.; Breuil, C. 1995. Extracellular lipase production by a sapwood- staining fungus Ophiostoma piceae. World J Microbial Biotechnol 11:638-642.

García-Lepe, R.; Nuero, O.M.; Reyes, F.; Santamaría, F. 1997. Lipases in autolysed cultures of filamentous fungi. Lett Appl Microbiol 25: 127-130.

Gopinath, S.C.B.; Anbu, P.; Hilda, A. 2005. Extracellular enzymatic activity profiles in fungi isolated from oil-rich environments. Mycoscience 46:116-126.

Gutiérrez, A.; Del Rio, J.; Martínez, A. 2009. Microbial and enzymatic control of pitch in the pulp and paper industry. Appl Microbiol Biotechnol 82:1005-1018.

Harrington, T. C.; McNew, D.; Steimel, J.; Hofstra, D.; Farrell, R. L. 2001. Phylogeny and taxonomy of the Ophiostoma piceae complex and the Dutch elm disease in fungi. Mycologia 93(1): 111-136.

Held, B.; Thwaites, J.; Farrell, R.; Blanchette, R. 2003. Albino strains of Ophiostoma species for biological control of sapstain fungi. Holzforschung 57: 237-242.

Hoshino, T.; Mizutani, A.; Shimizu, S.; Hidaka, H. 1991. Calcium ion regulates the release of lipase of Fusarium oxysporium. $J$ Biochem 110: 457-461.

Kontkanen, H.; Tenkanen, M.; Reinikainen, T. 2006. Purification and characterisation of a novel steryl esterase from Melanocarpus albomyces. Enz And Microbiol Technol 39: 265-273. 
Malkov, S.; Tikka, P.; Gullichsen, J. 2003. Towards complete impregnation of wood chips with aqueous solution. Paperija Puu-Paper and Timber 85 (8):1-14.

Martínez, M.J.; Barrasa, J.M.; Gutiérrez, A.; del Río, J.C.; Martínez, A. 2000. Fungal screening for biological removal extractives from Eucalyptus globulus. Can J Bot 77(10): 1513-1522.

Martínez- Iñigo, M.J.; Gutiérrez, A.; del Río, J.C.; Martínez, M.J.; Martínez, A.T. 2000. Time course of fungal removal of lipophilic extractives from Eucalyptus globulus wood. J Biotech 84:119-126.

Matsumura, J.; Oda, K.; Booker, R.; Ridoutt, B.; Donaldson, L. 2001. Flow pathways and resin content of Pinus radiate with pre steaming. $7^{\text {th }}$ International IUFRO Wood Drying Conference. Tsukuba, Japan, July 9-13. pp. 416-421.

Miller, D.; Knutson, D.; Tocher, R. 1983. Chemical brown staining of Douglas-fir sapwood. Forest Product Journal 33 (4): 44-48. $686 \mathrm{p}$

Montgomery, D. 2005. Diseño y Análisis de Experimentos. México. $3^{\text {era }}$ Edición. Editorial Limusa Wiley.

Navarrete, J.; Sanchez, R. 2005. Biorreducción del Pitch (resina) en madera de pino radiata. Informe Final Conicyt -Fondef D01i1160. Chile, Concepción, Universidad del Bío Bío.

Navarrete, J.; Segura, A.; Martínez, P.; Vera, R.; Segovia, C.; Herrera, P.; Reyes, L.; McNew, D.; Harrington, T.C.; Farrell, R.L.; Thwaites, J.M.; Held, B.; Blanchette, R.A. 2008. Control Biológico de la mancha azul en madera aserrada de Pinus radiata D.Don. The International Research Group on Wood Protection (IRG/WP 08-10681). Costa Rica, Guanacaste, 30 de Noviembre al 2 de Diciembre de 2008.

Navarrete, J.; Sánchez, R. 2010. Biotratamiento de la madera de Eucalyptus spp. para mejorar la eficiencia del proceso de pulpaje kraft. Informe Final Conicyt -Fondef D04i1223.

Rocheleau, M.J.; Sitholé, B.B.; Allen, L.H.; Iverson, R.; Farrell, R.; Noël, Y. 1998. Fungal treatment of Aspen chips for wood resin reduction: a laboratory evaluation. J Pulp Pap Sci 24 (2): 37-42.

Seifert, K.A. 1993. Sapstain of commercial lumber by species of Ophiostoma and Ceratocystis. In: Ceratocystis and Ophiostoma Taxonomy, Ecology and Pathogenicity. (Ed) Wingfield, Seifert and Webber. The American Phytopathological Society. St. Paul Minnesota. 293p.

Sharma, R.; Chisti, Y.; Banerjee, U.Ch. 2001. Production, characterization, and applications of lipases. Biotechnology Advances 19: 627-662.

Shukla, P.; Gupta, K. 2007. Ecological screening for lipolytic molds and process optimization for lipase production fron Rhizopus oryzae KG-5. Journal of Applied Sciences in Environmental Sanitation 2 (2): 35-42.

Sierra, G. 1957. A simple method for detection of lipolytic activity of microorganisms and some observations on the influence of the contact between cells and fatty substrates. Antoine van Leeuwenhoek 23: 15-22.

Slifkin, M. 2000. Tween 80 Opacity Test Responses of various Candida species. J Clin Microbiol 38 (12): 4626-4628

Sundqvist, B. 2002. Wood color control during kiln-drying. Forest Products Journal 52(2): 30-37.

Tamerler, C.; Martìnez, A.; Keshavarz, T. 2001. Production of lipolytic enzymes in batch cultures of Ophiostoma piceae. J Chem Technol Biotechnol 76: 991-996.

Wahid, Z.; Nadir, N. 2013. Improvement of one factor at a time through design of experiments. World Applied Science Journal (Mathematical Applications in Engineering) 21: 56-61.

Wang, Z.; Chen, T.; Gao, T.; Breuil, C.; Hiratsuka, Y. 1995. Biological degradation of resin acids in wood chips by wood-inhabiting fungi. Appl Environ Microbiol 61(1) : 222-225. 